\title{
MOTIVASI NASABAH DALAM BERTRANSAKSI RAHN PADA PT. PEGADAIAN SYARIAH UNIT PASAR BARU ABEPURA
}

\author{
Lady Afisyah Apriliani \\ IAIN Fattahul Muluk Papua \\ aprilianilady@gmail.com \\ Amirullah \\ IAIN Fattahul Muluk Papua \\ Jayapura.amir01@gmail.com \\ Fachrudin Fiqri Affandy \\ IAIN Fattahul Muluk Papua \\ affandyjo@gmail.com
}

\begin{abstract}
As the time goes on, Islamic Pawnshop Corp. has proven its development significantly by always optimizing the motivation of support in rahn transactions. In facing competitions, Islamic Pawnshop Corp. provides pawning items that can fulfill the needs of the community in the future. The pawning items are electronic equipment, Book vehicle owners (BPKB) and gold. By using the three items, the pawn services can serve deposit facilities and affordable prices.

The background of this research is the fierce competition between Islamic pawnshop financial institutions, especially toward conventional pawnshops, so that Islamic sharia pawnshops highlight the positive aspects of their products from conventional pawnshops. This study aims to determine the factors that motivate customers in transacting rahn and to find out what is done by pawnshops to motivate customers to trade rahn. The methodology used in this study is qualitative with primary and secondary data sources. The Data collection includes observation, interviews and documentation. Then, the data analysis uses the Miles and Huberman analysis method.

The results of this study indicate that the factors which motivate customers in transacting rahn include; marketing of rahn products through socialization, brochures, pamphlets or banners and the customer's interest in making rahn transactions for needs. The advantages of rahn transaction products are without interest, faster and cheaper transaction and low costs. However, the customer motivations in transacting rahn are urgent needs, business capital and school fees. Furthermore, the efforts made by the pawnshop in motivating customers to trade rahn include marketing of rahn products are through socialization, events, radio broadcasts, television, brochures, pamphlets or banners. Customer interest in rahn products is to increase capital and apply for microcredit. The existence of good service to customers has no interest. The motivation to transact rahn is based on needs.
\end{abstract}

Keywords: Motivation, Rahn, Islamic 


\begin{abstract}
ABSTRAK
Berkembangnya waktu pada saat ini PT. Pegadaian Syariah telah menunjukkan perkembangannya secara signifikan, dengan selalu mengoptimalkan motivasi nasabah dalam bertransaksi rahn. PT. Pegadaian Syariah dalam menghadapi persaingan yaitu dengan menyediakan produk gadai yang dapat memenuhi kebutuhan masyarakat di masa yang akan datang, dengan menyediakan produk gadai sertifikat, alat elektronik, BPKB dan emas yang merupakan layanan gadai dengan fasilitas titipan dan harga yang terjangkau.

Latar belakang penelitian ini adanya persaingan ketat antara lembaga keuangan pegadaian syariah terutama terhadap pegadaian konvensional, sehingga pegadaian syariah lebih mononjolkan segi positif produknya dari pegadaian konvensional. Penelitian ini bertujuan untuk mengetahui faktor yang memotivasi nasabah dalam bertransaksi rahn dan untuk mengetahui yang dilakukan oleh pegadaian untuk memotivasi nasabah bertransaksi rahn. Metodologi yang digunakan dalam penelitian ini adalah kualitatif dengan sumber data primer dan sekunder. Pengumpulan data meliputi observasi, wawancara dan dokumentasi. Sedangkan analisis data menggunakan metode analisis Miles dan Huberman.

Hasil dari penelitian ini menunjukkan bahwa faktor yang memotivasi nasabah dalam bertransaksi rahn diantaranya dari pemasaran produk rahn melalui sosialisasi, brosur, pamflet atau spanduk dan minat nasabah bertransaksi rahn untuk kebutuhan. Keunggulan produk bertransaksi rahn yaitu tidak ada bunga, lebih cepat, lebih murah, biayanya rendah dan motivasi nasabah dalam bertransaksi rahn dilatarbelakangi oleh kebutuhan mendesak, modal usaha dan biaya sekolah. Upaya yang dilakukan oleh pegadaian dalam memotivasi nasabah bertransaksi rahn diantaranya pemasaran produk rahn melalui sosialisasi, event, siaran radio, televisi, brosur, pamflet atau spanduk. Adanya minat nasabah terhadap produk rahn yaitu untuk menambah modal, mengajukan kredit mikro dan biaya sekolah. Adanya pelayanan yang baik kepada nasabah tidak ada bunga, dan motivasi bertransaksi rahn didasari pada kebutuhan.
\end{abstract}

Kata kunci: Motivasi, Rahn, Syariah 


\section{PENDAHULUAN}

Manusia sebagai makhluk hidup tidak akan bisa terlepas dari kegiatan-kegiatan yang berorientasi pada aspek pemenuhan kebutuhan hidup sehari-hari (Ekonomi). Ilmu ekonomi lahir bertujuan untuk membantu manusia dalam pemenuhan kebutuhannya. Islam merupakan suatu sistem dan jalan hidup yang utuh dan terpadu, islam yang memberikan panduan yang dinamis terhadap semua aspek kehidupan, termasuk sektor bisnis dan transaksi keuangan. Pegadaian merupakan tempat bagi nasabah untuk meminjam uang dengan barang-barang pribadi nasabah sebagai jaminannya. Mengusung slogan "Mengatasi Masalah Tanpa Masalah", PT. Pegadaian bahkan dinilai sebagai ekonomi kerakyatan. Hal ini didasarkan pada kenyataan bahwa masyarakat kelas bawah pun bisa memanfaatkan jasa gadai dari PT. Pegadaian (Zainul Arifin, 2002:8).

Pegadaian syariah atau yang dikenal dengan istilah rahn, dalam pengoperasiannya menggunakan metode fee based income (FBI) atau mudarabah (bagi hasil) (Andreas Harefa, 2020). Perbedaan mekanisme gadai syariah dengan yang ada sekarang (pegadaian konvensional) tentu saja dapat membingungkan bagi masyarakat yang sudah terbiasa dengan pegadaian konvensional. Adanya persaingan ketat antara lembaga keuangan pegadaian syariah terutama terhadap pegadaian konvensional. Karenanya, menjadi tantangan bagi pegadaian syariah untuk perlu melakukan kegiatan memperkenalkan pegadaian syariah, produk pegadaian syariah yang lebih menonjolkan segi positif atau nilai lebih dari pegadaian konvensional untuk mempertahankan nasabah dan dapat memotivasi nasabah.

Minat atau kepercayaan nasabah kepada pegadaian syariah unit pasar baru abepura harus ditumbuhkan. Oleh karena itu tim penjualan dan pemasaran khusus, harus perlu meningkatkan faktor yang memotivasi nasabah dan menonjolkan segi positif atau nilai lebih dari pegadaian konvensional. Selain itu, pengembangan konsep dan mekanisme gadai yang mengarah kepada upaya untuk menarik motivasi nasabah sangat diperlukan dan sangat penting untuk dilakukan dalam memperoleh nasabah dan mempertahankan nasabah. Keputusan untuk menggadai pada pegadaian syariah didasarkan atas berbagai pertimbangan. Sebuah premis dasar dalam teori perilaku konsumen adalah bahwa masyarakat akan cenderung untuk mengambil keputusan yang memberi nilai paling tinggi. Motivasi merupakan kekuatan pendorong dalam diri seseorang yang memaksa untuk melakukan suatu tindakan. Alasan yang memotivasi untuk mengambil keputusan disebut motif, motif ini muncul saat kebutuhan mencapai tingkat tertentu. Berdasarkan uraian tersebut, maka peneliti melakukan penelitian dengan mengangkat judul "Motivasi Nasabah Dalam Bertransaksi Rahn Pada PT. Pegadaian Syariah Unit Pasar Baru Abepura”. 


\section{KAJIAN LITERATUR}

\section{Konsep Pegadaian Syariah}

1. Pegadaian Syariah

Pegadaian berasal dari kata "gadai" yang berarti suatu hak yang diperoleh oleh seseorang yang mempunyai piutang atau suatu barang bergerak. Barang bergerak tersebut diserahkan kepada orang yang berpiutang oleh seseorang yang mempunyai utang atau orang lain atas nama orang yang mempunyai utang. Seseorang tersebut memberikan kuasa kepada orang yang berpiutang untuk menggunakan barang bergerak yang telah diserahkan untuk melunasi utang apabila pihak berutang tidak dapat melunasi kewajibannya saat jatuh tempo. Sedangkan perusahaan umum pegadaian adalah suatu badan usaha yang secara resmi mempunyai ijin untuk melaksanakan kegiatan lembaga keuangan dalam bentuk penyaluran dana kepada masyarakat atas dasar hukum gadai. Dalam menjalankan usahanya perusahaan ini mempunyai misi untuk (Susilo, 1999:67) :

a. Turut meningkatkan kesejahteraan masyarakat terutama golongan menengah ke bawah melalui penyediaan dana atas dasar hukum gadai dan bidang keuangan lainnya berdasarkan peraturan perundangan yang berlaku.

b. Menghindarkan masyarakat dari gadai gelap, riba, dan pinjaman tidak wajar lainnya.

Misi ini tertuang dalam Peraturan Pemerintah no. 103 tahun 2000. Dengan adanya misi ini dapat menunjukkan bahwa Perum Pegadaian tidak hanya bersifat comertial oriented tetapi lebih dari itu kepada social oriented. Dengan berorientasi kepada sosial, menjadikan pegadaian sebagai tempat alternatif bagi masyarakat untuk memperoleh uang dengan cepat tanpa syarat yang memberatkan khususnya bagi masyarakat kelas menengah ke bawah atau masyarakat yang membutuhkan dana yang mendesak dengan hanya menyerahkan barang sebagai jaminannya.

Sedangkan dalam islam, gadai atau rahn merupakan salah satu kategori dalam perjanjian utang piutang, yaitu demi suatu kepercayaan dari orang yang berpiutang, maka orang yang berhutang (rahin) memberikan barangnya sebagai jaminan (marhun) tersebut masih milik orang yang menggadaikan tetapi dikuasai oleh penerima gadai (murtahin). Gadai mempunyai nilai sosial yang tinggi dan dilakukan secara sukarela atas dasar tolong menolong.

2. Landasan Konsep Gadai Syariah

Boleh tidaknya transaksi gadai menurut islam, diatur dalam Al-Qur'an dan Sunnah.

a. Dalil yang memperbolehkan gadai, seperti yang tercantum dalam surat AlBaqarah, ayat 283 yang berbunyi sebagai berikut :

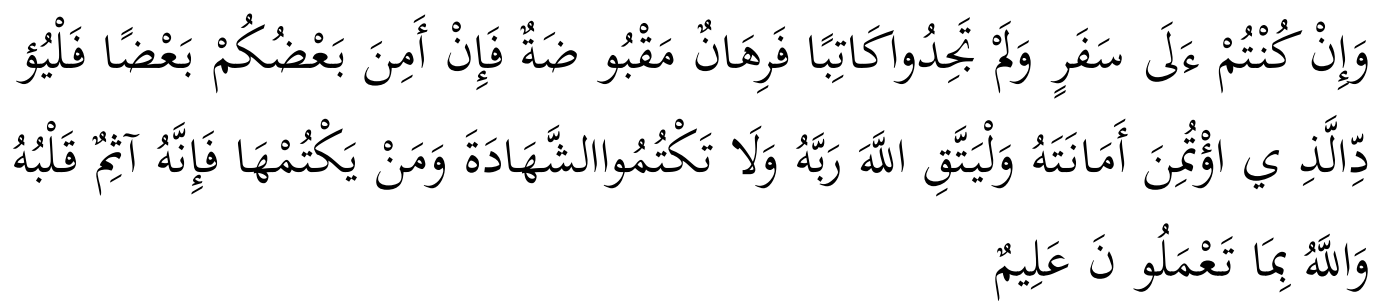


Terjemahannya: “Jika kamu dalam perjalanan (dan bermu'amalah tidak secara tunai) sedang kamu tidak memperoleh seorang penulis, Maka hendaklah ada barang tanggungan yang dipegang (oleh yang berpiutang). akan tetapi jika sebagian kamu mempercayai sebagian yang lain, Maka hendaklah yang dipercayai itu menunaikan amanatnya (hutangnya) dan hendaklah ia bertakwa kepada Allah Tuhannya; dan janganlah kamu (para saksi) Menyembunyikan persaksian. Dan Barang siapa yang menyembunyikannya, Maka Sesungguhnya ia adalah orang yang berdosa hatinya; dan Allah Maha mengetahui apa yang kamu kerjakan" (QS. Al-Baqarah: 283).

3. Sistem Operasional Gadai Syariah

Mekanisme operasional PT. Pegadaian Syariah dapat dilakukan melalui akad rahn, nasabah menyerahkan barang bergerak dan kemudian PT. Pegadaian Syariah menyimpan dan merawatnya di tempat yang telah disediakan oleh Pegadaian. Akibat yang timbul dari proses penyimpanan adalah timbulnya biaya-biaya yang meliputi nilai investasi tempat penyimpanan, biaya perawatan dan keseluruhan proses kegiatannya. Atas dasar ini dibenarkan bagi PT. Pegadaian Syariah mengenakan biaya sewa kepada nasabah sesuai jumlah yang disepakati oleh kedua belah pihak (Abdul Ghofur Anshori, 2011:126).

Pegadaian syariah dalam menjalankan operasionalnya berpegang pada prinsip syariah. Pada dasarnya produk-produk berbasis syariah, memiliki karakteristik seperti, tidak memungut bunga dalam berbagai bentuk karena riba, menetapkan uang sebagai alat tukar bukan sebagai komoditas yang diperdagangkan, dan melakukan bisnis untuk memperoleh imbalan atas jasa/bagi hasil. Payung hukum gadai syariah dalam hal pemenuhan prinsip-prinsip syariah berpegang pada fatwa DSN No.25/DSN-MUI/III/2002.

Pada dasarnya pegadaian syariah berjalan diatas dua akad transaksi syariah yaitu :

a. Akad Rahn

Akad rahn yang dimaksud adalah menahan harta milik si peminjam sebagai jaminan atas pinjaman, yang diterimanya pihak yang menahan memperoleh jaminan untuk mengambil kembali seluruh atau sebagian piutangnya.

b. Akad Ijarah

Yaitu akad pemindahan hak guna barang/jasa melalui pembayaran upah sewa, tanpa diikuti dengan pemindahan atas barangnya sendiri.

Berjalannya perjanjian gadai sangat ditentukan oleh banyak hal. Antara lain adalah subyek dan obyek perjanjian gadai. Subyek perjanjian gadai adalah rahin (yang bertransaksi rahn) dan murtahin (yang menahan barang gadai) obyeknya ialah marhun (barang gadai) dan utang yang diterima rahin. 


\section{Rukun Gadai Syariah}

a. Aqid, adalah pihak-pihak yang melakukan perjanjian (shigat). Aqid terdiri dari dua pihak yaitu: pertama, rahin (yang menggadaikan) yaitu orang yang telah dewasa, berakal, bisa dipercaya, dan memiliki barang yang akan digadaikan. Kedua, murtahin (yang menerima gadai), yaitu orang, bank, atau lembaga yang dipercaya oleh rahin untuk mendapatkan modal dengan jaminan barang (gadai).

b. Marhun, (barang yang digadaikan) yaitu barang yang digunakan rahin untuk dijadikan jaminan dalam mendapatkan uang.

c. Marhun bih, (utang) yaitu sejumlah dana yang diberikan murtahin kepada rahin atas dasar besarnya tafsiran marhun.

Sighat (ijab dan kabul) yaitu kesepakatan antara rahin dan murtahin dalam melakukan transaksi gadai (Zaenudin Ali, 2008:22).

\section{Motivasi}

\section{Pengertian Motivasi}

Motivasi berasal dari bahasa latin yang berbunyi movere yang berarti dorongan atau menggerakkan. Pentingnya motivasi karena motivasi adalah hal yang menyebabkan, menyalurkan, dan mendukung perilaku manusia. Motivasi berasal dari keinginan seseorang untuk memenuhi suatu kebutuhan, sedangkan kebutuhan manusia beraneka ragam dan tidak terbatas. Motivasi akan mendorong individu untuk melakukan suatu tindakan tertentu, perilaku ini dipengaruhi karena adanya tujuan tertentu atau kebutuhan yang belum terpenuhi. Motivasi berperan penting dalam mempengaruhi perilaku nasabah, maka dari itu motivasi nasabah sangat penting untuk dipahami (Abraham H. Maslow, 1984:39).

2. Jenis-jenis Motivasi

Jenis-jenis motivasi yang terjadi atas dasar pembentukannya menurut Sardiman terbagi atas 2 (dua) jenis, yaitu :

a. Motivasi bawaaan, yaitu motivasi yang dilatarbelakangi oleh fisio kemis di dalam tubuh seseorang yang telah dibawah sejak lahir dan terjadinya tanpa dipelajari.

b. Motivasi yang dipelajari, yaitu motivasi yang terjadi karena adanya komunikasi dan isyarat sosial serta secara sengaja dipelajari oleh manusia.

\section{Fungsi Motivasi}

Sardiman mengemukakan bahwa proses timbulnya dorongan sehingga nasabah tergerak untuk membeli suatu produk itulah yang disebut motivasi, sedangkan yang memotivasi untuk membeli disebut motif (Suryani, 2008:27). Motif juga bisa diartikan sebagai suatu alasan seseorang dalam melakukan suatu tindakan, dari sinilah motivasi mempengaruhi perilaku konsumen. Fungsi-fungsi motivasi sebagai berikut :

a. Motif bersifat mengarahkan dan mengatur tingkah laku individu. Tingkah laku individu dikatakan bermotif jika tindakanya bergerak menuju kearah tertentu. 
Ketika seseorang memiliki tujuan tertentu, maka setiap tindakan yang dilakukan akan mengarah pada hal-hal yang dapat mencapai tujuan yang dikehendakinya.

b. Motif sebagai penyeleksi tingkah laku individu. Motif yang terdapat dalam diri seseorang akan membuat seseorang tersebut bertindak secara terarah pada suatu tujuan yang diniatkan diawal.

4. Proses Motivasi

Motivasi muncul karena adanya suatu kebutuhan atau tujuan yang belum terpenuhi sehingga seseorang terdorong untuk memenuhi tercapainya tujuan tersebut. Setelah kebutuhan yang diinginkan terpenuhi, maka akan muncul kebutuhankebutuhan lain yang menuntut untuk dipenuhi. Inilah dinamakan motivasi yang terjadi pada diri manusia (Sciffman dan Kanuk, 2008:72). Timbulnya proses motivasi didasari oleh tiga unsur utama yaitu : kebutuhan, perilaku dan tujuan.

5. Dinamika Proses Motivasi

Agar pemberian motivasi berjalan dengan lancar, maka harus ada proses motivasi yang jelas karena motivasi konsumen yang dilakukan oleh produsen sangat erat kaitannya dengan kepuasan konsumen untuk itu perusahaan selalu berusaha untuk membangun kepuasan konsumen dengan berbagai cara. Berikut adalah proses motivasi yang terdiri dari: "Tujuan, mengetahui kepentingan, komunikasi efektif, integrasi tujuan, dan fasilitas (Setiadi J. Nugroho, 2013:30).

6. Teori Motivasi

a. Teori Hierarki Kebutuhan

Teori ini dikemukakan oleh Abraham Maslow (Maslow's Hierarchy of Needs). Maslow mengemukakan bahwa manusia memiliki lima kebutuhan berdasarkan tingkat kepentingannya, kebutuhan tersebut yaitu : (Philip Kotler dan Kevin Lane Keller, 2011:179). Kebutuhan fisiologis, kebutuhan keamanan, kebutuhan sosial, keputuhan penghargaan diri dan kebutuhan aktualisasi diri. Menurut teori Maslow, dari kelima kebutuhan tersebut manusia berusaha memenuhi kebutuhanya dari tingkat yang paling dasar sebelum memenuhi kebutuhannya yang lebih tinggi. Ketika kebutuhan dasar telah terpenuhi, maka akan muncul kebutuhan lain yang lebih tinggi dan begitu seterusnya.

\section{Akad Rahn}

\section{Pengertian Akad}

Menurut Syamsul Anwar, bahwa istilah "perjanjian" disebut" akad" dalam hukum Islam. Kata akad berasal dari kata al- aqd, yang berarti mengikat, menyambung atau menghubungkan (ar-rabt) (Ahmad Ab al-Fath, 2007:68). Makna "ar-rabt" secara luas dapat diartikan sebagai ikatan antara beberapa pihak. Arti secara bahasa ini lebih dekat dengan makna istilah fiqh yang bersifat umum, yakni keinginan seseorang untuk melakukan sesuatu, baik keinginan bersifat pribadi maupun keinginan yang terkait dengan pihak lain.

Menurut Syamsul Anwar, akad adalah pertemuan ijab dan kabul sebagai pernyataan dua pihak atau lebih untuk melahirkan suatu akibat hukum pada 
obyeknya. Secara lebih jelas akad dapat diartikan sebagai pengaitan ucapan salah seorang yang melakukan akad dengan yang lainnya secara syara' pada segi yang tampak dan berdampak pada obyeknya, sehingga akad merupakan salah satu sebab peralihan harta yang ditetapkan syara' yang karenanya timbul beberapa hukum berdasarkan persetujuan kedua belah pihak.

2. Berakhirnya Akad

Pada dasarnya, suatu akad berakhir bila telah tercapai tujuan dari akad tersebut. namun, selain itu ada sebab lain yang dapat membuat suatu akad berakhir, meskipun tujuannya belum tercapai. Para ulama fiqih menetapkan sebab-sebab itu sebagai berikut :

a. Berakhirnya masa berlaku akad, apabila akad tersebut memiliki tenggang waktu

b. Dibatalkan oleh para pihak yang ber-akad, apabila akad itu sifatnya mengikat dan dapat dibatalkan

c. Akad yang telah sah dan mengikat, dianggap berakhir jika: akad itu dinyatakan fasad, berlakunya syarat khiyar (dapat memilih meneruskan akad atau tidak), atau akad itu tidak dilaksanakan oleh salah satu pihak.

\section{METODE PENELITIAN}

Pendekatan dan Jenis Penelitian adalah melakukan penelitian ilmiah haruslah sesuai dengan prinsip-prinsip dan metode ilmiah. Oleh karenanya, diperlukan adanya metodologi atau rancangan penelitian yang mencakup berbagai aspek dan langkahlangkah yang ditempuh oleh peneliti dalam melaksanakan penelitiannya.

Adapun penelitian ini digolongkan ke dalam penelitian deskriptif kualitatif, yaitu penelitian yang diarahkan untuk memberikan gejala-gejala, fakta-fakta atau kejadiankejadian secara sistematis dan akurat mengenai daerah tertentu (J. Lexy Moleong, 1998:121).

\section{Subjek dan Objek Penelitian}

\section{Subjek}

Subjek penelitian adalah merujuk pada informan yang hendak dimintai atau digali datanya. Maka, subjek dalam penelitian ini adalah Nasabah pada PT.Pegadaian Syariah Unit Pasar Baru Abepura.

2. Objek

Objek penelitian adalah merujuk pada nasabah atau tema yang sedang diteliti. Maka, objek dalam penelitian ini adalah Motivasi Nasabah dalam bertransaksi rahn pada PT.Pegadaian Syariah Unit Pasar Baru Abepura sebanyak 15 orang.

\section{Jenis Data dan Teknik Pengumpulan Data}

\section{Jenis Data}

Dalam hal ini data yang penulis gunakan ialah data primer dan data sekunder. Data primer adalah data yang diperoleh melalui wawancara dengan sumber atau pihak yang terkait. Data sekunder dapat berupa buku, catatan, data dokumentasi atau arsip 
baik yang dipublikasikan maupun yang tidak dipublikasikan secara umum (Syafizal Helmi, 2010:2).

2. Teknik Pengumpulan Data
a. Observasi
b. Wawancara
c. Dokumentasi

\section{Teknik Analisis}

Analisis data merupakan proses mencari, mengatur secara sistematis, semua transkrip wawancara, catatan lapangan dan bahan-bahan lain yang telah terhimpun untuk memperoleh pengetahuan mengenai data tersebut dan mengkomunikasikan apa yang telah ditemukan.

Oleh karena itu, data pada penelitian ini berwujud kata-kata, kalimat-kalimat, atau paragraf-paragraf yang ditanyakan dalam bentuk narasi yang bersifat deskriptif, dengan menggunakan kata-kata walaupun tidak menutup kemungkinan terdapat data yang berupa angka.

Penerapan teknik analisis deskriptif kualitatif yang dilakukan Miles dan Huberman (Mattew B. Miles dan A Michael Huberman, 1992:21). melalui tiga jalan kegiatan yang merupakan satu kesatuan (saling terkait) yaitu 1). Reduksi data. 2). Display data, 3). Mengambil kesimpulan dan verifikasi.

\section{HASIL DAN PEMBAHASAN}

\section{Hasil}

a. Faktor Yang Memotivasi Nasabah Dalam Bertransaksi Rahn Pada PT. Pegadaian Syariah Unit Pasar Baru Abepura.

1) Adanya pemasaran produk rahn sehingga nasabah termotivasi bertransaksi rahn.

Berdasarkan hasil wawancara dengan beberapa informan yang merupakan nasabah PT. Pegadaian Syariah Unit Pasar Baru Abepura menunjukkan bahwa ada proses pemasaran melalui sosialisasi, brosur, pamflet/spanduk.

2) Adanya minat nasabah terhadap produk rahn.

Berdasarkan hasil wawancara dengan beberapa informan yang merupakan nasabah PT. Pegadaian Syariah Unit Pasar Baru Abepura menunjukkan bahwa minat bertransaksi rahn untuk kebutuhan.

3) Keunggulan yang diberikan kepada nasabah.

Berdasarkan hasil wawancara dengan beberapa informan yang merupakan nasabah, menunjukkan bahwa keunggulan bertransaksi rahn pada PT. Pegadaian Syariah Unit Pasar Baru Abepura adalah tidak ada bunga, lebih cepat, lebih murah, dan biayanya rendah.

4) Motivasi nasabah bertransaksi rahn dilatarbelakangi adanya kebutuhan.

Berdasarkan hasil wawancara dengan beberapa informan yang merupakan nasabah, menunjukkan bahwa motivasi bertransaksi rahn pada PT. 
Pegadaian Syariah Unit Pasar Baru Abepura adalah kebutuhan mendesak, modal usaha dan biaya sekolah.

\section{b. Upaya Yang Dilakukan Oleh Pegadaian Dalam Memotivasi Nasabah} Bertransaksi Rahn Pada PT. Pegadaian Syariah Unit Pasar Baru Abepura.

1) Adanya pemasaran produk rahn sehingga nasabah termotivasi bertransaksi rahn.

Berdasarkan wawancara tersebut terlihat bahwa pemasaran pada PT. Pegadaian Syariah Unit Pasar Baru Abepura ditangani langsung oleh pegawai, tim pemasar khusus yang memasarkan produk secara global dan melalui sosialisasi, event, siaran radio, televisi, brosur, pamflet/spanduk.

2) Minat nasabah terhadap produk rahn.

Berdasarkan wawancara tersebut terlihat bahwa minat nasabah bertransaksi rahn pada PT. Pegadaian Syariah Unit Pasar Baru Abepura untuk menambah modal, mengajukan kredit mikro, dan biaya sekolah.

3) Pelayanan yang baik kepada nasabah.

Berdasarkan wawancara tersebut terlihat bahwa keunggulan yang diberikan kepada nasabah bertransaksi rahn pada PT. Pegadaian Syariah Unit Pasar Baru Abepura adalah pelayanan yang baik dan tidak ada bunga.

4) Motivasi bertransaksi rahn didasarkan pada kebutuhan.

Berdasarkan wawancara tersebut terlihat bahwa motivasi nasabah bertransaksi rahn pada PT. Pegadaian Syariah Unit Pasar Baru Abepura adalah kebutuhan mendesak dan modal usaha.

\section{Pembahasan}

a. Faktor Yang Memotivasi Nasabah Dalam Bertransaksi Rahn Pada PT. Pegadaian Syariah Unit Pasar Baru Abepura

1) Pemasaran produk rahn

Pemasaran produk rahn sangat penting bagi nasabah PT. Pegadaian Syariah Unit Pasar Baru Abepura sebagai proses timblunya dorongan minat dalam diri nasabah. Berdasarkan hasil wawancara dengan beberapa informan di atas yang merupakan nasabah PT. Pegadaian Syariah Unit Pasar Baru Abepura menunjukkan bahwa ada proses pemasaran melalui sosialisasi, brosur dan pamflet/spanduk.

Jika dibandingkan dengan teori dalam fungsi motivasi, proses timblunya dorongan minat sehingga nasabah tergerak untuk membeli suatu produk itulah yang disebut motivasi, sedangkan untuk mengenal suatu produk melalui sosialisasi. Maka teori yang dipakai sesuai dengan hasil yang ditemukan peneliti dilapangan yaitu nasabah mengenal produk gadai rahn melalui sosialisasi, brosur dan pamflet/spanduk.

Penelitian yang dilakukan oleh Devi Silviana tentang Analisis Faktorfaktor Yang Mempengaruhi Minat Nasabah Non Muslim Menjadi Nasabah di 
Pegadaian Syariah Kantor Cabang Sidoarjo menampilkan hasil penelitian mengenai faktor yang paling dominan dalam mempengaruhi minat nasabah non muslim menjadi nasabah di Pegadaian Syariah Kantor Cabang Sidoarjo adalah faktor reputasi. Penelitian Devi Silviana tersebut selaras dengan penelitian ini bahwa nasabah mengenal produk rahn melalui sosialisasi, brosur dan pamflet/spanduk pada PT. Pegadaian Syariah Unit Pasar Baru Abepura.

2) Minat Nasabah terhadap produk rahn

Motif juga bisa diartikan sebagai suatu alasan seseorang dalam melakukan suatu tindakan, dari sinilah motivasi mengarahkan perilaku konsumen. Berdasarkan hasil wawancara dengan beberapa informan di atas yang merupakan nasabah PT. Pegadaian Syariah Unit Pasar Baru Abepura menunjukkan bahwa minat bertransaksi rahn untuk kebutuhan.

Jika dibandingkan dengan teori dalam fungsi motivasi, proses timblunya dorongan sehingga nasabah tergerak untuk membeli suatu produk itulah yang disebut motivasi, sedangkan yang memotivasi untuk membeli disebut motif. Motif juga bisa diartikan sebagai suatu alasan seseorang dalam melakukan suatu tindakan, dari sinilah motivasi mempengaruhi perilaku konsumen, maka teori yang dipakai sesuai dengan hasil yang ditemukan peneliti dilapangan yaitu nasabah PT. Pegadaian Syariah Unit Pasar Baru Abepura menunjukkan bahwa minat bertransaksi rahn untuk kebutuhan.

Penelitian ini selaras dengan penelitian yang dilakukan oleh Melen Sterendisa tentang Faktor-Faktor Yang Mempengaruhi Minat Nasabah Terhadap Produk Gadai (Rahn) di PT. Pegadaian Syariah (KCP Samping Patal Palembang) hasil penelitian mengenai Faktor Psikologis, yaitu dorongan dalam diri nasabah, Faktor Sosial yang mempengaruhi nasabah yaitu keluarga, rekan kerja, dan tetangga, Faktor Ekonomi yang mempengaruhi nasabah yaitu nasabah menggadaikan emas karena nasabah membutuhkan uang. Penelitian Melen Sterendisa tersebut selaras dengan penelitian ini berupa minat nasabah bertransaksi rahn pada PT. Pegadaian Syariah Unit Pasar Baru Abepura untuk kebutuhan.

3) Keunggulan produk rahn

Keunggulan produk rahn yang nasabah dapatkan pada PT. Pegadaian Syariah Unit Pasar Baru Abepura dapat memotivasi nasabah bertansaksi rahn. Berdasarkan hasil wawancara dengan beberapa informan di atas yang merupakan nasabah, menunjukkan bahwa keunggulan bertransaksi rahn pada PT. Pegadaian Syariah Unit Pasar Baru Abepura adalah tidak ada bunga, lebih cepat, lebih murah dan biayanya rendah.

Jika dibandingkan dengan teori dalam motivasi, keunggulan yang diberikan kepada nasabah, nasabah tergerak untuk memilih suatu produk itulah yang disebut motivasi. Dalam teori kebutuhan Maslow manusia memiliki lima kebutuhan berdasarkan tingkat kepentingannya, maka teori yang dipakai sesuai dengan hasil yang ditemukan peneliti dilapangan yaitu menunjukkan bahwa 
keunggulan bertransaksi rahn pada PT. Pegadaian Syariah Unit Pasar Baru Abepura adalah tidak ada bunga, lebih cepat, lebih murah dan biayanya rendah.

Penelitian yang dilakukan oleh Anisfathur Rohman tentang Tingkat Kepuasan Nasabah Bertransaksi Rahn di Pegadaian Syariah Cabang Kusumanegara Yogyakarta menampilkan hasil penelitian mengenai kepuasan nasabah terhadap kinerja Pegadaian Syariah Cabang Kusumanegara. Penelitian Anisfathur Rohman tersebut selaras dengan penelitian ini berupa adanya keunggulan bertransaksi rahn pada PT. Pegadaian Syariah Unit Pasar Baru Abepura adalah tidak ada bunga, lebih cepat, lebih murah, dan biayanya rendah.

4) Motivasi Nasabah

Minat sebagai suatu dorongan dalam diri nasabah untuk mengambil keputusan berdasarkan kebutuhan. Berdasarkan hasil wawancara dengan beberapa informan di atas yang merupakan nasabah PT. Pegadaian Syariah Unit Pasar Baru Abepura menunjukkan bahwa motivasi bertransaksi rahn pada PT. Pegadaian Syariah Unit Pasar Baru Abepura adalah kebutuhan mendesak, modal usaha dan biaya sekolah.

Jika dibandingkan dengan teori dalam motivasi, nasabah tergerak untuk memilih suatu produk itulah yang disebut motivasi dan nasabah termotivasi bertansaksi rahn. Dalam teori kebutuhan Maslow manusia memiliki lima kebutuhan berdasarkan tingkat kepentingannya, maka teori yang dipakai sesuai dengan hasil yang ditemukan peneliti dilapangan yaitu PT. Pegadaian Syariah Unit Pasar Baru Abepura menunjukkan bahwa motivasi nasabah bertransaksi rahn pada PT. Pegadaian Syariah Unit Pasar Baru Abepura untuk kebutuhan mendesak, modal usaha dan biaya sekolah.

Penelitian ini selaras dengan penelitian yang dilakukan oleh Mukhlis Adib tentang Faktor-Faktor Yang Mempengaruhi Masyarakat Dalam Memilih Produk Rahn di Kantor Cabang Pegadaian Syariah Ciputat, hasil penelitian mengenai masyarakat memilih pegadaian syariah untuk menggadai barang mereka karena faktor kebutuhan konsumsi dan pengembangan usaha. Penelitian Mukhlis Adib tersebut selaras dengan penelitian ini berupa motivasi nasabah bertransaksi rahn pada PT. Pegadaian Syariah Unit Pasar Baru Abepura untuk kebutuhan mendesak, modal usaha dan biaya sekolah.

\section{b. Upaya Yang Dilakukan Oleh Pegadaian Dalam Memotivasi Nasabah Bertransaksi Rahn Pada PT. PegadaianSyariah Unit Pasar Baru Abepura.}

1) Pemasaran produk rahn

Pemasaran produk rahn sangat penting bagi PT. Pegadaian Syariah Unit Pasar Baru Abepura sebagai proses timblunya dorongan minat dalam diri nasabah. Berdasarkan wawancara yang dilakukan peneliti kepada pihak pegadaian tersebut terlihat bahwa pemasaran pada PT. Pegadaian Syariah Unit Pasar Baru Abepura ditangani langsung oleh pegawai, tim pemasar khusus 
yang memasarkan produk secara global dan melalui sosialisasi, event, siaran radio, televisi, brosur, pamflet/spanduk.

Jika dibandingkan dengan teori dalam fungsi motivasi, proses timblunya dorongan minat sehingga nasabah tergerak untuk membeli suatu produk itulah yang disebut motivasi, sedangkan untuk mengenal suatu produk melalui pemasaran. Maka teori yang dipakai sesuai dengan hasil yang ditemukan peneliti dilapangan yaitu PT. Pegadaian Syariah Unit Pasar Baru Abepura menunjukkan bahwa ada proses pemasaran melalui sosialisasi, event, siaran radio, televisi, brosur dan pamflet/spanduk.

Penelitian yang dilakukan oleh Devi Silviana tentang Analisis Faktorfaktor Yang Mempengaruhi Minat Nasabah Non Muslim Menjadi Nasabah di Pegadaian Syariah Kantor Cabang Sidoarjo menampilkan hasil penelitian mengenai faktor yang paling dominan dalam mempengaruhi minat nasabah non muslim menjadi nasabah di Pegadaian Syariah Kantor Cabang Sidoarjo adalah faktor reputasi. Penelitian Devi Silviana tersebut selaras dengan penelitian ini berupa adanya pemasaran produk rahn melalui sosialisasi, event, siaran radio, televisi, brosur dan pamflet/spanduk pada PT. Pegadaian Syariah Unit Pasar Baru Abepura.

2) Minat Nasabah terhadap produk rahn

Motif juga bisa diartikan sebagai suatu alasan seseorang dalam melakukan suatu tindakan, dari sinilah motivasi mengarahkan perilaku konsumen. Berdasarkan hasil wawancara yang dilakukan peneliti kepada pihak pegadaian menunjukkan bahwa minat nasabah bertransaksi rahn pada PT. Pegadaian Syariah Unit Pasar Baru Abepura untuk menambah modal, mengajukan kredit mikro, dan biaya sekolah.

Jika dibandingkan dengan teori dalam fungsi motivasi, proses timblunya dorongan sehingga nasabah tergerak untuk membeli suatu produk itulah yang disebut motivasi, sedangkan yang memotivasi untuk membeli disebut motif. Motif juga bisa diartikan sebagai suatu alasan seseorang dalam melakukan suatu tindakan, dari sinilah motivasi mempengaruhi perilaku konsumen, maka teori yang dipakai sesuai dengan hasil yang ditemukan peneliti dilapangan yaitu PT. Pegadaian Syariah Unit Pasar Baru Abepura menunjukkan bahwa minat nasabah bertransaksi rahn pada PT. Pegadaian Syariah Unit Pasar Baru Abepura untuk menambah modal, mengajukan kredit mikro, dan biaya sekolah.

Penelitian ini selaras dengan penelitian yang dilakukan oleh Melen Sterendisa tentang Faktor-Faktor Yang Mempengaruhi Minat Nasabah Terhadap Produk Gadai (Rahn) di PT. Pegadaian Syariah (KCP Samping Patal Palembang) hasil penelitian mengenai Faktor Psikologis, yaitu dorongan dalam diri nasabah, Faktor Sosial yang mempengaruhi nasabah yaitu keluarga, rekan kerja, dan tetangga, Faktor Ekonomi yang mempengaruhi nasabah yaitu nasabah menggadaikan emas karena nasabah membutuhkan uang. Penelitian Melen Sterendisa tersebut selaras dengan penelitian ini berupa minat nasabah 
bertransaksi rahn pada PT. Pegadaian Syariah Unit Pasar Baru Abepura untuk menambah modal, mengajukan kredit mikro, dan biaya sekolah.

3) Pelayanan yang baik kepada nasabah

Keunggulan produk rahn pada PT. Pegadaian Syariah Unit Pasar Baru Abepura dapat memotivasi nasabah bertansaksi rahn. Berdasarkan hasil wawancara yang dilakukan peneliti kepada pihak Pegadaian menunjukkan bahwa keunggulan nasabah bertransaksi rahn pada PT. Pegadaian Syariah Unit Pasar Baru Abepura adalah pelayanan yang baik dan tidak ada bunga.

Jika dibandingkan dengan teori dalam motivasi, keunggulan yang diberikan kepada nasabah, nasabah tergerak untuk memilih suatu produk itulah yang disebut motivasi. Dalam teori kebutuhan Maslow manusia memiliki lima kebutuhan berdasarkan tingkat kepentingannya, maka teori yang dipakai sesuai dengan hasil yang ditemukan peneliti dilapangan yaitu PT. Pegadaian Syariah Unit Pasar Baru Abepura menunjukkan bahwa keunggulan bertransaksi rahn pada PT. Pegadaian Syariah Unit Pasar Baru Abepura adalah pelayanan yang baik dan tidak ada bunga.

Penelitian yang dilakukan oleh Anisfathur Rohman tentang Tingkat Kepuasan Nasabah Bertransaksi Rahn di Pegadaian Syariah Cabang Kusumanegara Yogyakarta menampilkan hasil penelitian mengenai kepuasan nasabah terhadap kinerja Pegadaian Syariah Cabang Kusumanegara. Penelitian Anisfathur Rohman tersebut selaras dengan penelitian ini berupa adanya keunggulan bertransaksi rahn pada PT. Pegadaian Syariah Unit Pasar Baru Abepura adalah pelayanan yang baik dan tidak ada bunga.

4) Motivasi Nasabah

Minat sebagai suatu dorongan dalam diri nasabah untuk mengambil keputusan berdasarkan kebutuhan. Berdasarkan hasil wawancara dengan pihak Pegadaian menunjukkan bahwa motivasi nasabah bertransaksi rahn pada PT. Pegadaian Syariah Unit Pasar Baru Abepura untuk kebutuhan mendesak dan modal usaha.

Jika dibandingkan dengan teori dalam motivasi, nasabah tergerak untuk memilih suatu produk itulah yang disebut motivasi dan nasabah termotivasi bertansaksi rahn. Dalam teori kebutuhan Maslow manusia memiliki lima kebutuhan berdasarkan tingkat kepentingannya, maka teori yang dipakai sesuai dengan hasil yang ditemukan peneliti dilapangan yaitu PT. Pegadaian Syariah Unit Pasar Baru Abepura menunjukkan bahwa motivasi nasabah bertransaksi rahn pada PT. Pegadaian Syariah Unit Pasar Baru Abepura untuk kebutuhan mendesak dan modal usaha.

Penelitian ini selaras dengan penelitian yang dilakukan oleh Mukhlis Adib tentang Faktor-Faktor Yang Mempengaruhi Masyarakat Dalam Memilih Produk Rahn di Kantor Cabang Pegadaian Syariah Ciputat, hasil penelitian mengenai masyarakat memilih pegadaian syariah untuk menggadai barang mereka karena faktor kebutuhan konsumsi dan pengembangan usaha. 
Penelitian Mukhlis Adib tersebut selaras dengan penelitian ini berupa motivasi nasabah bertransaksi rahn pada PT. Pegadaian Syariah Unit Pasar Baru Abepura untuk kebutuhan mendesak dan modal usaha.

\section{KESIMPULAN DAN SARAN \\ Kesimpulan}

Berdasarkan hasil penelitian yang peneliti lakukan dapat disimpulakan:

1. Faktor yang memotivasi nasabah dalam bertaransaksi rahn yaitu: adanya pemasaran melalui sosialisasi, brosur dan pamflet/spanduk. Minat nasabah bertransaksi rahn pada PT. Pegadaian Syariah Unit Pasar Baru Abepura yaitu untuk kebutuhan. Keunggulan nasabah bertransaksi rahn yaitu tidak ada bunga, lebih cepat, lebih murah, dan biayanya rendah. Motivasi nasabah bertransaksi rahn adalah kebutuhan mendesak, modal usaha dan biaya sekolah.

2. Upaya yang dilakukan oleh pegadaian untuk memotivasi nasabah yaitu: adanya pemasaran melalui sosialisasi, event, siaran radio, televisi, brosur, pamflet/spanduk. Minat nasabah bertransaksi rahn yaitu untuk menambah modal, mengajukan kredit mikro dan biaya sekolah. Keunggulan yang di berikan nasabah dalam bertransaksi rahn adalah pelayanan yang baik dan tidak ada bunga. Motivasi nasabah bertransaksi rahn untuk kebutuhan.

\section{Saran}

1. Bagi perusahaan

Sebagian besar nasabah tertarik dengan produk gadai emas melalui sosialisasi, kegiatan maupun sosialisasi yang dilakukan kepada nasabah secara langsung oleh pegawai maupun tim pemasar. Diharapkan sosialisasiyang dilakukan selanjutnya dapat semakin ditingkatkan guna menarik semakin banyak nasabah dan termotivasi pada produk gadai sertifikat, alat elektronik dan BPKB. Kemudian, diharapkan Pegadaian Syariah dapat meningkatkan kualitas produk dan segala atribut yang menyertai produk gadai sertifikat, alat elektronik, BPKB dan emas, untuk mempertahankan nasabah yang telah bergabung dan menarik nasabah baru, baik yang sudah sering bertransaksi di Pegadaian maupun belum.

2. Bagi peneliti selanjutnya

Diharapkan hasil penelitian ini dapat dijadikan referensi bagi penulis lain untuk penelitian mendatang guna memperoleh hasil penelitian yang lebih luas, maka disarankan untuk menambah variabel lain yang tidak diteliti dalam penelitian ini. 


\section{DAFTAR REFERESI}

Ahmad Ab al-Fath. Hukum Perjanjian syariah Studi tentang Teori Akad dalam Fikih Muamalat. Jakarta: PT. Raja Grafindo Persada, 2007.

Ali, Zaenudin. hukum gadai syariah. Jakarta: Sinar Grafika, 2008.

Andreas Harefa, dkk. "Perum Pegadaian bukan Sekedar Gadai" http://www.sinarharapan.co.id/ekonomi/eureka/2004/1119/eurl.html.

Anshori, Abdul Ghofur. Gadai Syariah di Indonesia. Yogyakarta: Gajah Mada University Press, 2011.

Arifin, Zainul. Dasar-dasar Menejemen Bank Syariah. Jakarta: Alvabet, 2002.

Departemen Agama RI, Al-Quran dan Terjemahannya, Semarang: Lajnah Pentashih Mushaf Al-Quran Departemen Agama RI, 1992.

Kotler, Philip dan Kevin Lane Keller. Manajemen Pemasaran. Jakarta: Edisi 13 Jilid 1 dan 2, Alih Bahasa : Bob Sabran, Erlangga, 2011.

Maslow, Abraham H. Motivasi dan Kepribadian. Jakarta: PT. Gramedia, 1984.

Miles Mattew B. dan Huberman A. Michael. Analisis Data Kualitatif. Jakarta: Universitas Indonesia, 1992.

Moleong J. Lexy. Metode Pendidikan Kualitatif. Bandung: Remaja Rosda Karya, 1998.

Nugroho J. Setiadi. Perilaku Konsumen. Jakarta: Kencana Perdana Media Grup, 2013.

Sciffman dan Kanuk. Perilaku Konsumen. Jakarta: Indeks, 2008.

Suryani. Perilaku Konsumen Implikasi Pada Strategi Pemasaran. Yogyakarta: Graha Ilmu, 2008.

Susilo. Bank dan Lembaga Keuangan Lainnya. Jakarta: Salemba Empat, 1999.

Syafizal Helmi Syafizal. Analisis Data : Untuk Reset Manajemen dan Bisnis. Medan: Usu Press, 2010. 